\title{
Hybrid Learning of Daviq.com in the Subject of Teaching Listening and Speaking
}

\author{
Daviq Rizal \\ UIN Walisongo Semarang \\ daviqr@walisongo.ac.id
}

\begin{abstract}
The term hybrid learning was used to describe online learning combined with face-to-face interaction in the classroom. There are two research questions the first question is how the development of hybrid learning in http://daviqr.com/ is. The second one is how the moodle-based hybrid learning of http://daviqr.com/ as a teaching model in the subject of teaching listening and speaking to the students of English Department of IAIN Walisongo Semarang in the academic year of 2013/2014 is. This research is a research and development, which has the population of all fourth semester English department students of the Faculty of Teachers' Training and Education, IAIN Walisongo Semarang that takes the subject of Teaching Listening and Speaking in the academic year 2013/2014, which consists of three classes. The number of population is 120 students. Regarding the research findings that there are some main reasons why most students agree that the hybrid learning course is an exciting course and why they prefer the hybrid online course or the combination between online and traditional classroom. First, the course outline and objectives were made clear. Second, they learned a lot from this hybrid course. Third, the reading materials were clear and informative. Fourth, the level of this hybrid course is just right. Fifth, the total study load of this hybrid course is in proportion to the number of semester credits is just right. Sixth, the amount of their interaction with other students is a little better. Seventh, the quality of their interaction with other students is a little better. Eighth, the amount of their interaction with the instructor is a little better. Ninth, the quality of their interaction with the instructor is a little better and about the same. Tenth, compared to a face-toface (traditional) class of equal credits, the workload of this online course is somewhat more. There are some recommendations I should give. First, UIN Walisongo Semarang must design e-learning for lecturers as many students like hybrid courses. Second, the faculty must improve the quality of Wi-Fi hotspots.
\end{abstract}

\section{ARTICLE HISTORY}

Received 27 April 2017

Accepted 19 September 2017

\section{KEYWORDS}

hybrid learning; face-to-face interaction; course outline; combination;

\section{Introduction}

Hybrid learning, a combination of multimedia technology, CD ROM video streaming, virtual classrooms, voicemail, email and conference calls and online text animation and video streaming ${ }^{1}$, is a new trend in some universities in Indonesia 
including IAIN Walisongo Semarang. Hybrid learning helps the face-to-face setting in the classroom. Since February until August 2011 Tarbiyah faculty of IAIN Walisongo Semarang in association with DBE2 Semarang tried out online learning on six subjects namely Computer-Assisted Language Learning, Cell Biology, Study Methodology of Islam, Environmental Chemistry, History of Islamic Civilization and Arabic Language Study in DBE2 website http://ptkonline.org. However, since DBE2 programs were closed, the implementation of online learning in FITK ended. To solve the problems, the Moodle-based website was created in http://daviqr.com to teach some of my subjects such as discourse study, computer-assisted language learning, and teaching listening and speaking.

Hybrid learning refers to the intentional use of networked information and communication technology in teaching and learning. Allison Littlejohn and Chris Pegler further explained that hybrid learning has several definitions. First, it is an access to a wide choice of resources on your personal computer. Second, it is an online studying with facilitators within a course. Third, it is an activity of downloading content to mobile devices, using podcast and e-books as resources ${ }^{2}$. Hybrid learning includes e-learning in which there are other terms to describe elearning such as online learning, virtual learning, distributed learning, network, and web-based learning. Basically they refer to the same thing, that is, educational processes that utilize information and communication technology to mediate asynchronous and synchronous learning and teaching activities. The term hybrid learning has a wider scope than online, virtual, distributed, networked or web-based learning. It stands for electronic learning. It incorporates all educational activities of individuals or groups working offline or online ${ }^{3}$.

The term hybrid learning was used to describe online learning combined with additional solutions such as mentoring, training, etc. Hybrid learning can take many forms such as conducting a new employee orientation in a classroom followed up with e-mails and electronic checklists, holding traditional workshops or seminars combined with e-mail dialogues to answer questions, providing classroom instruction on new computer software, followed by job training and so forth ${ }^{4}$.

Hybrid learning is similar to online learning, which is significant for economic advancement both for individuals and society. As today's economy is dependent on a labor force, the labor force can continue to learn the necessary training through online learning. It happens in response with the changing economy. Workers need to

\footnotetext{
2 Allison Littlejohn and Chris Pegler, Preparing for Blended e-Learning, (UK, Routledge, 2007), p.9

3 Som Naidu, Ph.D., E-learning: A Guidebook of Principles, Procedures and Practices, (New Delhi:CEMCA, 2006), p.1

4 Diann Wilson and Ellen Smilanich, The Other Hybrid learning: A Classroom-Centered Approach, (USA: Pfeifer, 2005), p.14
} 
learn new skills, and online learning is the solution in response to a society's need for lifelong rapid learning 5 .

However, online learning deals with anything delivered, enabled or mediated by electronic technology for learning. This definition also excludes non-electronic things such as books and paper-based correspondence. It includes web-based learning and computer-based training as they occur in learning communities ${ }^{6}$.

Moreover, online learning is a generic term describing the integration of information and communications technology into learning and teaching both on and off campus. This method has been adopted to students who are unable to attend on campus. Online learning can range from static pages of websites displayed on the Internet to complex multimedia interactive productions and can include online discussion groups. However, most sites promoted individual rather than collaborative learning, instruction rather than inquiry, clicking rather than communicating and automatic feedback rather than guidance and memorization rather than knowledge construction ${ }^{7}$.

As the university lecturers are required to go beyond selecting a textbook for their students, the exploration of hybrid learning is essential. Hybrid learning can enrich their teaching and learning experiences through online environments. The weakness of online learning is on the lack of face-to-face contact. Hence, it has resulted in the mix of hybrid learning and traditional conventional classroom, widely known as hybrid learning ${ }^{8}$.

In brief, hybrid learning is an integration of various techniques of teaching and learning, in which it combines the face-to-face interaction in the classroom and online learning using moodle-based websites. In each session, students might have three features in their moodle-based websites in all subjects including the subject of teaching listening and speaking such as online reading materials, online discussion forum, quiz or assignment.

The research questions will be systematized as follows.

1. How is the development of moodle-based hybrid learning in http://daviqr.com/?

2. How is the moodle-based hybrid learning of http://daviqr.com/ as a teaching model in the subject of teaching listening and speaking to the

$5 \quad$ Eli B Cohen \& Malgorzata Nycz, Learning Objects and E-learning: an Informing Science Perspective, available from http://ijklo.org/Volume2/v2p023-034Cohen32.pdf, p.1

6 Fee, Kenneth, Delivering hybrid learning: a Complete Strategy for Design, Application and Assessment, (UK:Kogan Page Ltd, 2009), p.15

$7 \quad$ King, Caroline, Blended Is Better: Choosing Educational Delivery Methods, (New Zealand, 2005), available from hyperdisc.unitec.ac.nz/research/KingMcsporranEdmedia2005.pdf (August 2, 2011)

8 Holmes, Bryn and Gardner, John, hybrid learning: Concept and Practice, (London:SAGE Publications Ltd, 2006), p.10 
students of English Department of IAIN Walisongo Semarang in the academic year of 2013/2014?

\section{Review of Related Literature}

\section{Discussion Forums}

Discussion forums are a powerful communication tool within a blended Moodle course. In discussion forum, there are message boards where the lecturer and his students can post messages to each other while easily keeping track of individual conversations. Forums are the primary tool for online discussion and are the central organizing feature in the hybrid online course.

Forums allow the lecturer and students to communicate with each other at any time, from anywhere with an Internet connection. Students do not have to be logged in at the same time to communicate with people or their classmates. The technical term for this type of communication is asynchronous or "not at the same time." Asynchronous communications are contrasted with synchronous forms such as chat rooms, instant messaging, or face-to-face conversations.

Because forums are asynchronous, students can get their time composing replies. They can sketch and redraft until they are pleased with the results instead of feeling under pressure to reply instantly. The asynchronous nature of the forums creates many opportunities for students not only to duplicate the conversations you have in class but also to produce wholly new activities that are difficult in a classroom setting? .

\section{Quiz}

Evaluation of students' performance is a critical part of a learning environment, and assessment is one of the most important activities in education. As lecturers, we cannot tell what's going on inside students' heads, so we need a way for them to demonstrate what they comprehend and what they do not. A well-made test, even a multiple-choice test, can give students valuable information about students' misconceptions. If the feedback is rapid enough, it can also be a critical tool for students to measure their performance and help them become successful.

Moodle's quiz module is one of the most complex pieces of the system. The community has added a large number of options and tools to the quiz engine, making it extremely flexible. Teachers can create quizzes with different question types, randomly generate quizzes from pools of questions, letting students re-take quizzes multiple times, and get the computer score everything.

These features signal some strategies that usually aren't practical with paperbased testing. It is hard enough to score one batch of quizzes, and nearly impossible

\footnotetext{
${ }^{9}$ Cole, Jason \& Foster, Helen, Using Moodle: Teaching with the Popular Open Source Course Management System ( $2^{\text {nd }}$ Edition), (USA: O’Reilly Media, Inc, 2008), p.69
} 
to score it ten times for each student. When the computer does the work for teachers, it is not hard to give students a chance to practice taking a test or give frequent small quizzes.

Moodle quizzes contain two major components: the quiz body and the question pools. Quiz bodies act as containers for various types of questions from the question pools. The body is what students see when they take the evaluation. It also defines how the students work with the quiz. The questions in a quiz body can be of any kind, selected manually or at random, and displayed in a set or random order. The question pools can have questions arranged in a manner that makes sense to students. Pools can be reused in multiple quizzes, shared between classes and courses, and even moved between systems ${ }^{10}$.

\section{Survey}

Moodle has two tools for collecting feedback from the students: surveys and choices. A survey is a set of prearranged questions. It is not possible to create questions in a survey if teachers do not install a nonstandard module such as Questionnaire or Feedback. Getting feedback from students about the nature of the course is focused on by the current survey.

Choices are small, one-question surveys, which act as small web polls that teachers may have seen on other websites. Teachers can use a choice to obtain rapid feedback from students about any topic teachers desire, as long as it is only one question long.

There are three types of surveys in Moodle. First, COLLES (Constructivist On-Line Learning Environment Survey) is a set of 24 statements that asks students about the relevance of the course, provides opportunities for reflection and interactivity, provides peer and tutor support, and facilitates interpretation. These factors are based on the social constructivist theory. Variations on the survey asked students to talk about their actual learning environment or the preferred learning environment.

Moodle offers three types of COLLES surveys namely preferred, actual, or a combination of the two. The preferred COLLES survey asks students to discuss how they believe they want to interact with a course, while the actual COLLES survey asks them how they are interacting at present.

ATTLS (Attitudes to Thinking and Learning Survey) ATTLS seeks to determine the quality of interaction within a course, which builds on the "Separate and Connected ways of knowing" scale. The Critical Incidents survey asks students to reflect on recent events and reply questions about their relationship to those events $^{11}$.

\footnotetext{
${ }^{10}$ Cole, Jason \& Foster, Helen, Using Moodle: Teaching with the Popular Open Source Course Management System ( $2^{\text {nd }}$ Edition), (USA: O'Reilly Media, Inc, 2008), p.95

${ }^{11}$ Cole, Jason \& Foster, Helen, Using Moodle: Teaching with the Popular Open Source Course Management System (2 ${ }^{\text {nd }}$ Edition), (USA: O'Reilly Media, Inc, 2008), p.203
} 


\section{Assignment}

Assignments are a straightforward method for collecting student work. They are a flexible and straightforward catch-all for things teachers want to grade. The assignment module gives teachers an easy way to let students upload digital content for grading. Students can be asked to submit essays, spreadsheets, presentations, web pages, photographs, or small audio or video clips. Anything they can save on their hard drives can be submitted in response to an assignment.

Assignments do not have to consist of file uploads. The teacher can create offline assignments they need to complete. Alternatively, the teacher can ask students to answer directly into the assignment itself.

Assignments are a useful tool teachers can utilize in creative ways to gather more authentic responses from students than is possible with the quiz engine ${ }^{12}$.

\section{Blended Learning}

\section{Hybrid learning}

The hybrid learning is a kind of education, which combines a various model of face-to-face interaction and distance education model by using all the facilities of technology. In other words, it is the combination of face to face and online learning. The hybrid learning also combines the strongest sides of face to face and web supported education.

The first thing decided when designing a hybrid learning environment is the determination of the topic part used in hybrid learning and the part that will be used in the classroom. The most common practice was merging the topic half to half. The levels of the face to face and online supports is dependent not only the on the decision of the applier but also the physical conditions. The application level of the online methods determines the content presented and the balance between the learning methods. LMS (Learning Management System) is the most suitable method for the transfer of the contents to the face to face method, which otherwise is very difficult to present and enables us to repeat the content depending upon the learning level and facilitates the online submission of the texts. The information repeated determines the extent of face to face and online applications in the blended process ${ }^{13}$.

\footnotetext{
${ }^{12}$ Cole, Jason \& Foster, Helen, Using Moodle: Teaching with the Popular Open Source Course Management System (2 ${ }^{\text {nd }}$ Edition), (USA: O'Reilly Media, Inc, 2008), p.123

${ }^{13}$ Dikmenli, Yurdal and Unaldi UE, The Effect of the Hybrid learning Environment and the Application of Virtual Class upon the Achievement and the Attitude against the Geography Course in Mevlana International Journal of Education Vol. 3 (2), 1 August 2013, Available online at http://mije.mevlana.edu.tr/
} 


\section{Hybrid learning Models}

The use of the term hybrid learning is not relatively old in both higher education and corporate settings. In higher education, the term "hybrid course" was often used before the appearance of the term "hybrid learning," and now the two terms are used interchangeably. Because the term is relatively new, there are still ongoing debates regarding the precise meaning and relevance of the term. This definition highlights the ongoing union of two model learning environments: the traditional face-to-face environment with the technology-mediated environment.

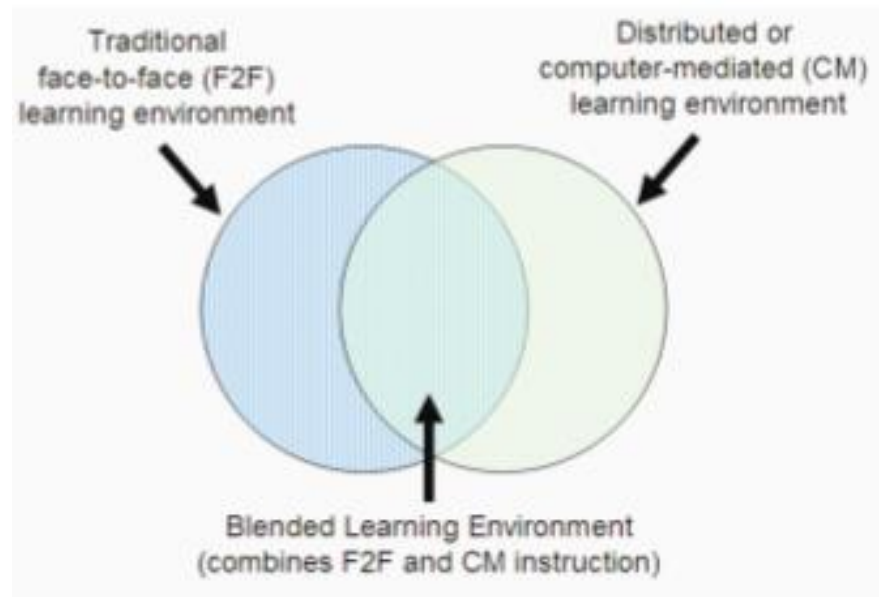

Figure 1. Hybrid learning

There are many reasons why a blended approach selected. The three most common reasons for blending are to increase learning effectiveness, to increase convenience and access and to increase cost-effectiveness. Often lecturers adopt a blended approach to explore balances between more than one of these goals simultaneously. Hybrid learning is attractive to many people because it enables one to take advantage of the best of both models namely traditional course and online course. The hybrid learning environment can also mix the least effective methods of both models if not well designed.

The concept of hybrid learning is simple and exciting. Nevertheless, there are many ways that hybrid learning can be implemented in a variety of different contexts. For this reason, it is important to share successful models of hybrid learning so that all can benefit. Sharing models of hybrid learning can help to facilitate the purposeful and disciplined implementation of appropriate hybrid learning strategies. This section of the article will present several models of hybrid learning. Because of space constraints, it is not possible to share all of the details of the models, but a rich set of references is provided that will allow the reader to find additional details for the examples of interest.

It is necessary to understand that blending occurs at many different levels including the institutional level, the program level, the course level, and the activity 
level. Naturally, models at the course and activity levels have instructor stakeholders who are mainly interested in issues of learning effectiveness and productivity. Hybrid learning that occurs at the program and institutional levels typically have administrator stakeholders who are often determined by issues of cost-effectiveness and expanding access of the learning to available audiences.

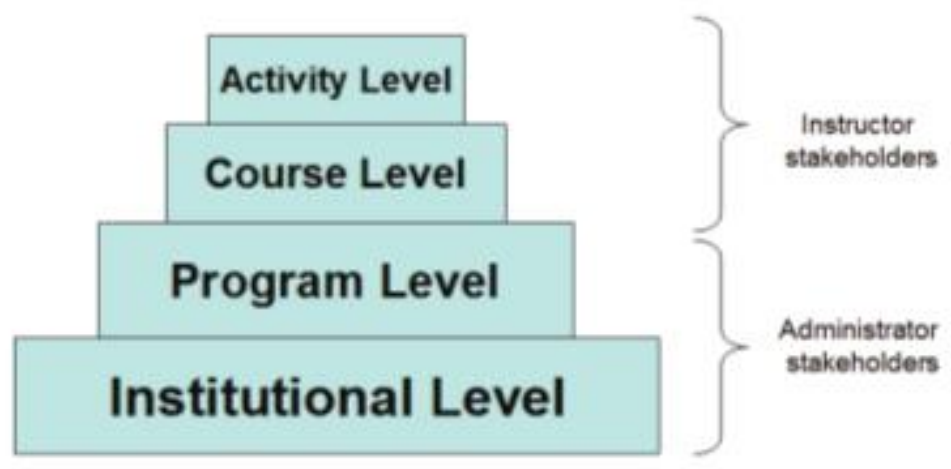

Figure 2. Different Levels of Hybrid learning

It is difficult to predict what the future holds for hybrid learning environments. It is possible that the use of hybrid learning in both higher education and corporate contexts will keep on growing. There may come a time when the traditional learning environment is mainly a hybrid learning environment and it no longer makes sense to use the adjective "blended.". Rather than they focus on whether blending is happening or not, universities will focus more on the quality of the hybrid learning and find out how faculty can be trained and supported to teach in hybrid learning environments $^{14}$.

Finally, Bonk, Kim and Zeng make 10 predictions related to hybrid learning in the future:

a. The use of mobile devices in hybrid learning increased.

b. The use of visualization tools and hands-on learning in hybrid learning greater.

c. The learner input in the design of their own learning programs increases.

d. The connectedness, community, and collaboration increases.

e. The authenticity and on-demand learning increases.

f. The ties between work and learning are stronger.

g. Calendaring system will need modifying and be more flexible.

h. Programs will commence to include hybrid learning course designations.

\footnotetext{
${ }^{14}$ Graham, Charles R, 2008, Hybrid learning Models. Available from http://ebooks.narotama.ac.id/files/Encyclopedia\%20of\%20Information\%20Science\%20and\%20Tech nology\%20\%282nd\%20Edition\%29/Blended\%20Learning\%20Models.pdf, p.375
} 
i. Instructor roles will gradually move toward that of mentor, coach and counselor

j. Hybrid learning specialist teaching certificates will appear ${ }^{15}$.

\section{Characteristics of Hybrid learning Course}

Regarding hybrid learning course, there are benefits and challenges of hybrid learning. There are two major groups: student perspective and student challenges. In student perspective, there are some advantages.

A. Benefits

Students involved in hybrid learning courses are generally very positive about their experiences. The main reason that students gave for their high level of satisfaction was the time flexibility provided by hybrid learning.

B. Time Flexibility

Time flexibility is defined as the skill to control the pace of one's learning, the convenience of scheduling coursework and the decrease in time spent commuting. Students liked the hybrid learning because it provided them with the flexibility to work from home. Working from home was more positive than working from other locations. The hybrid learning also provided them with a greater range of course scheduling options because of the face-to-face class time.

C. Improved student learning outcomes

Several research studies showed that hybrid learning designs contribute to improved learning outcomes for students. At the University of Wisconsin in Milwaukee, students learn more in blended courses than they do in traditional courses. Students wrote better papers, performed better on exams, produced higher quality projects and were capable of more important discussions on course material.

Besides student perspective, there are student challenges as well. First, students new to hybrid learning spend more time in traditional classes than online courses. Moreover, they do not spend in lectures at work, but they see time spend online at work. Second, time management is struggling. Online activities are required to be completed between the face-to-face classes. Third, responsibility for learning can be very difficult for students accustomed to being passive learners within a traditional classroom. Initially, students are unprepared for the active learning role they must play in a blended course. Fourth, most technology related problems usually occur within the first weeks of the semester or during orientation meetings of online

\footnotetext{
${ }^{15}$ Bonk, C.J, Kim, K.J \& Zeng, T, Future Directions of Hybrid learning in Higher Education and Workplace Settings, (San Fransisco:Pfeiffer Publishing, 2005), p.550-567
} 
courses. These problems include the procedure for accessing the online components such as web site address and logon information ${ }^{16}$.

\section{Research Methodology}

\section{Research Approaches}

This research is a research and development. Research and development (R\&D) are also recognized in Europe as research and technical (or technological) development (RTD), which is a broad term for activities related to the enterprise of corporate or governmental innovation. The activities classified as $R \& D$ vary from company to company, but there are two primary models, with an R\&D department being either staffed by engineers and tasked with directly developing new products, or staffed with industrial scientists and tasked with applied research in scientific or technological fields which may assist future product development. R\&D differs from the vast majority of corporate activities in that it is not often intended to make an immediate profit, and generally carries greater risk and an uncertain return on investment.

\section{Time and Place}

\section{a. Time}

This research will be conducted in the academic year of 2013/2014.

\section{b. Place}

It will be conducted in some classes: TBI 4A, TBI 4B, TBI 4C of the English Department of IAIN Walisongo Semarang as it has the subject of Teaching Listening and Speaking in daviqr.com.

\section{Population and Sample}

\section{a. Population}

The population is all fourth semester English department students of the Faculty of Teachers' Training and Education, IAIN Walisongo Semarang that takes the subject of Teaching Listening and Speaking in the academic year 2013/2014, which consists of three classes. The number of population is 120 students.

\section{b. Sample}

As the number of the population is 120 , the purposive sampling is used. The sampled participants will be chosen from those, who participate actively in 2 features of daviqr.com: the reading materials and online discussion. Those answering the instruments are only those involved in reading materials, online discussion forum and quiz or assignment.

\footnotetext{
${ }^{16}$ Vaughan, Norman, Perspective on Hybrid learning in Higher Education in International Journal on ELearning, Proquest, p.84
} 


\section{Research Instruments}

\section{a. Survey}

The survey could be regarded as the method of data collection by asking some questions in writing to the selected participants. The survey was done in according to two types of questions: closed and open questions.

\section{b. Documentation}

Documentation refers to the method where the researcher investigates written object such as student attendance, online reading materials, online discussion forum, scores of quiz and assignment, etc. ${ }^{17}$

\section{c. Observation}

Observation is carried out in the face-to-face classroom and online classroom.

\section{Data Collection}

Each of the three data collection such as survey, observation, and documentation will produce different kinds of data. The type of data in the survey is collected through the online survey at http://daviqr.com/. The observation will cover the students' participation in the online discussion forum, reading materials, and quiz or assignment. The documentation will include student attendance in the online and offline class, scores of quizzes and assignments and reading materials of each session.

\section{Data Analysis}

The survey with closed questions will be analyzed based on the percentage. Open questions on the survey, similar to interview in nature, will be analyzed in a more detail description. After that, the documentation including the reading materials, scores of the quiz, an online discussion forum will be discussed as well. The documentation will complete the data. Afterward, the analysis of observation will be described.

\section{Research Findings}

\section{The development of Moodle-based Hybrid learning in http://daviqr.com/}

After the ptk-online.org from DBE2 was closed, I initially created my website by buying a domain and hosting. Besides, IAIN Walisongo Semarang does not provide Moodle-based e-learning for lecturers. Hence, http://daviqr.com/ was created, and Moodle was installed. 


\section{Hybrid learning Course in the Subject of Teaching Listening and Speaking as a Teaching Model}

As a teaching model, hybrid learning course in the subject of Teaching Listening and Speaking is interesting. Many students - 89 out of 120 students, participated in the survey. The questions and answers of the survey will be discussed here.

Regarding the components of the hybrid online course students like is a mostly online discussion forum. They can learn more and use the easy and interesting method. Besides, they can get clear knowledge. It can make them engage with technology closely. It can give them knowledge, insight, and experience. Students enjoy posting opinions and comments in the online discussion. It is more attractive. Reading materials are also their favorite components. Students also like the assignment and quizzes.

What students dislike from hybrid learning varies. Some students dislike the assignment every week. Also, they have limited time to do the quiz so that they have to rush. Besides, students need fast data connection to join the hybrid online class. Students dislike reading online materials before they do the quiz or test.

Students also expect help from the faculty. Some of them expect more Wi-Fi hotspots to improve the data connection speed. They expect the faculty to provide many computers and access to the internet. Mostly, students complain about the internet connection in the faculty.

Students think that the hybrid online courses should continue. They say that the continuation of hybrid courses is useful for them.

Students suggest that hybrid online courses can be improved by improving hotspot at the campus and create a new learning model. Some students complain about the deadline of the assignment and quiz. They want time extension.

\section{Conclusion and Recommendations}

\section{Conclusions}

IAIN Walisongo Semarang does not provide Moodle-based e-learning for lecturers. Hence, http://daviqr.com/ was created, and Moodle was installed.

There are some main reasons why most students agree that the hybrid learning course is an exciting course and why they prefer the hybrid online course or the combination of online and traditional classroom. First, the course outline and objectives were made clear. Second, they learned a lot from this hybrid course. Third, the reading materials were clear and informative. Fourth, the level of this hybrid course is just right. Fifth, the total study load of this hybrid course is in proportion to the number of semester credits is just right. Sixth, the amount of their interaction with other students is a little better. Seventh, the quality of their interaction with other students is a little better. Eighth, the amount of their interaction with the instructor is a little 
better. Ninth, the quality of their interaction with the instructor is a little better and about the same. Tenth, compared to a face-to-face (traditional) class of equal credits, the workload of this online course is somewhat more.

On average they have spent less than 3 hours on this course including reading materials, online discussions, quizzes, and assignments. However, most students have not enrolled in any classes previously and more female than male participated in the survey.

Regarding the components of the hybrid online course students like is a mostly online discussion forum. What students dislike from hybrid learning varies. Some students dislike the assignment every week. Also, they have limited time to do the quiz so that they have to rush. Students also expect help from the faculty. Some of them expect more Wi-Fi hotspots to improve the data connection speed. They expect the faculty to provide many computers and access to the internet. Mostly, students are a complaint about the internet connection in the faculty. Students think that the hybrid online courses should continue.

\section{Recommendations}

There are some recommendations I should give. First, IAIN Walisongo Semarang must design e-learning for lecturers as many students like hybrid courses. Second, the faculty must improve the quality of Wi-Fi hotspots so that students feel cared on their hybrid online courses. Third, the implementation of hybrid online courses should be given to other lecturers so that students acquire what they need.

\section{References}

Addision, Wesley. (2001). Teaching by Principle: An Interactive Approach to Language Pedagogy. New York: Longman

Anderson, Mark \& Kathy Anderson. (2003). Text Types in English 1-2. Australia: Macmillan Education

Bonk, C.J, Kim, K.J \& Zeng, T. (2005). Future Directions of Hybrid learning in Higher Education and Workplace Settings. San Fransisco: Pfeiffer Publishing

Caladine, Richard. (2008). Enhancing hybrid learning with Media-Rich Content and Interactions. New York: Information Science Publishing

Cameron, Lynne. (2001). Teaching Language to Young Learners. Cambridge: Cambridge 
Chapelle, Carol A. (2003). English Language Learning and Technology. Amsterdam: John Benjamins Publishing Company

Cole, Jason \& Foster, Helen. (2008). Using Moodle: Teaching with the Popular Open Source Course Management System (2 ${ }^{\text {nd }}$ Edition). USA: O'Reilly Media, Inc

Fraenkle, Jack R. and Norman E. Wallen. (2006). How to Design and Evaluate Research in Education 6th Ed. New York: The McGraw-Hill Companies

Garrison, D Randy, and Vaughan, Norman D. (2008). Hybrid learning in Higher Education: Framework, Principles, and Guidelines. California: Jossey-Bass

Graham, Charles R. (2008). Hybrid learning Models. Available from http://ebooks.narotama.ac.id/files/Encyclopedia\%20of\%20Information\%20Sci ence $\% 20$ and $\% 20$ Technology $\% 20 \% 282$ nd\%20Edition $\% 29 /$ Blended $\% 20$ Learni ng\%20Models.pdf

Grellet, Frangoise. (2001). Developing Reading Skills, UK: Cambridge University Press

Harmer, The Practice of English Language Teaching Longman Handbooks for Language Teacher, London: Longman Ninth Impression, (2001).

Harper, Richard. (2006). eLearning and Digital Publishing. UK: Springer

Hennings, Dorothy Grant. (1999). Reading with Meaning Strategies for College Reading. USA: Prentice Hall

J. B. Heaton. (1975). Writing English Language Test. London: Longman

King, Kathleen P. (2009). Hybrid learning. USA: Fordham University

Kotzer1, Shulamit and Yossi Elran2. (2006). "'1st Moodle Research Conference Heraklion, Crete-Greece, September, 14 - 15, 2012” Davidson Institute of Science Education, Weizmann Institute of Science, Rehovot: Israel in "Digital Literacies for Learning" by Allan Martin (Editor) and Dan Madigan (Editor), Facet Publishing

Littlejohn, Allison and Pegler, Chris. (2007). Preparing for Blended e-Learning. USA: Routledge 
Omaggio, Alice C. (1986). Teaching Language in Context. Massachusetts: Heinle \&Heinle Publisher

Rice IV, William H. (2006). Moodle hybrid learning Course Development. Mumbai: Packt Publishing

Sandra Fotos and Charles M. Browne. (2004). New Perspectives on CALL for Second Language Classrooms. London: Lawrence Erlbaum Associates

Scovel, Thomas. (2009). Psycholinguistics, New York: Oxford University Press

Sharifi, Farzad an (Ed). (2009). English as an International Language Perspectives and Pedagogical Issues. Canada: Multilingual Matters

Smaldino, Sharon E. et al. (2012). Instructional Technology and Media for Learning. Boston: Pearson Education, Inc

Stanford, Jeff. (2009). Moodle 1.9 for Second Language Teaching. Mumbai: PACKT Publishing

Thorne, Kaye. (2003). Hybrid learning: How to Integrate Online and Traditional Learning. USA: Kogan Page Limited

Vaughan, Norman. (2007). Perspective on Hybrid learning in Higher Education in International Journal on Elearning. ProQuest

Wilson, Diann, and Smilanich, Ellen. (2005). The Other Hybrid learning: A Classroom-Centered Approach. California: Pfeiffer

Dikmenli, Yurdal and Unaldi UE. (2013). The Effect of the Hybrid Learning Environment and the Application of Virtual Class upon the Achievement and the Attitude against the Geography Course in Mevlana International Journal of Education Vol. 3 (2), 1 August 2013, Available online at http://mije.mevlana.edu.tr/ 